DOI: http://dx.doi.org/10.24093/awejtls/vol1no2.1

\title{
Bans and Boundaries: The Arab Layman in Zakaria Tamer's Sour Grapes
}

\author{
May Witwit \\ Hon. Research Fellow \\ University of Bedfordshire, United Kingdom
}

\begin{abstract}
Social diseases, incompetent governments and the effeminate existence of the Arab person are recurrent themes in Zakaria Tamer's Sour Grapes (2000). Set in a fictitious Syrian neighbourhood, the stories of the collection Sour Grapes identify the bans and boundaries burdening contemporary Arab life. By presenting the unusual and the nonsensical, Tamer highlights not only the socio-political and economic problems but the impact of the various social customs and inaccurate interpretations of religious teachings on gender roles and on all that burdens the sheer existence of the Arab individual. The novelist does not name a figure or a regime but compels his reader to question the quality of existence in a working class Arab neighbourhood. Written in (2000), the collection foresees the inevitability of an Arab uprising, which was to take place ten years later. Unlike the stereotypical observations of many orientalists, Tamer's Sour Grapes takes his readers through the narrow alleys of Queiq, introducing them to the Arab layman. Through the characters' defiance or their commitment to the social bans and religious prohibitions, Tamer discloses the deep crisis in the Arab social fabric. Through textual analysis and the explanation of inherited bans and boundaries, this paper highlights Tamer's clever use of the ridiculous to demonstrate how dictators are instated in most aspects of Arab life. This paper looks deeply into some of Tamer's short stories to explain what lies between the lines and the ideas behind Tamer's depiction of the bizarre and the peculiar to demonstrate how the powerful people in an Arab society thrive at the expense of the simple Arab person and his culture.

Keywords: Arabic fiction, Syrian fiction, Arab Social life, Arab social customs, Fictional representation of Arabs, Religious misinterpretation
\end{abstract}

Cite as: Witwit, M. (2017). Bans and Boundaries: The Arab Layman in Zakaria Tamer's Sour Grapes. Arab World English Journal for Translation \& Literary Studies, 1(2).

DOI:http://dx.doi.org/10.24093/awejtls/vol1no2.1 
AWEJ for translation \& Literary Studies Volume, 1 Number 2, May 2017

Bans and Boundaries: The Arab Layman in ZakariaTamer's Sour Grapes Witwit

Only when the Arabic novel reaches the stage of expressing itself beautifully and eloquently, it can face the real challenge and boldly introduce itself without the need to borrow the fingers or the masks of others. (Abdul-RahmanMunief (1933-2004))

\section{Introduction}

Preferring to disguise his criticism Zakaria Tamer combines the unusual, the grotesque and the ridiculous to convey his message. In Sour Grapes (2000), Tamer highlights some of the sociopolitical diseases affecting Arab life. Although he attempts to presents his characters as ordinary humans, their actions and the events betray far more complex concepts than the reader might initially think. Those familiar with his works know that he concentrates on the contradictions of existence and the Arab person's struggle between what they feel and think and the prevalent restrictions and taboos governing their lives and limiting their self-expression. Born in 1931 Tamer witnessed many events and experienced various hardships. His style of writing landed him in trouble with the Syrian regime and he was banned from writing for the Syrian newspapers. His satire of the Shah of Iran, in the 1970s, almost led to his receiving a severe punishment. ${ }^{1} \mathrm{He}$ left Syria in 1981 to settle in the UK. Several of his short-story collections have been translated to English such as Tigers on the Tenth Day (1985), Spring in the Ashes (1994), Breaking Knees (2008), and The Hedgehog (2009).

Tamer's stories indirectly reveal what is missing in Arab life and magnify the generally accepted argument that there is little freedom of speech and equality among people in the Arab world. Lack of self-expression, blind obedience and divorce are recurrent themes employed by the writer to magnify the harm done to the common man in the Arab world. Thus he compels his reader to question whether or not the popular attitudes and beliefs governing the Arabs' way of life encourage the rise of unchecked authoritarian regimes, which intentionally obstruct the emergence of a democratic political culture, and lead to the creation of small dictators in every aspect of life. Sour Grapes can be seen as an eye-opener for the Arab reader and those wishing to see Arab life from the inside. Unlike some of the impressionistic and anecdotal information, influenced by dominant Western discourse, Tamer's deep knowledge of the culture enables him to take his readers on a journey in the narrow alleys of Queiq where his men and women come to life, introducing the reader to the Arab layman or what is sometimes described as the Arab street.

Although some of the stories do not exceed a paragraph or two in length, the questions they raise prevent the reader from passing them as mere folktales. In 'The Silent', for example, the protagonist receives an anonymous slap with every insincere flattery he utters. The depiction of physical and moral weaknesses raises several questions about the quality of life. Through exaggerated events and characters, Tamer indirectly challenges political setups, beliefs and social customs that impede the political, cultural and religious progress of the Arab individual. The writer not only highlights almost every aspect of Arab life, he also depicts Western colonisation and its attempts to wipe out the Arab national identity. It is also worth noting that many years later a number of Tamer's predictions do actually take place, such as the Arab Spring and the return of Western troops to the region. Although the stories take place in a fictitious Syrian neighbourhood, they easily represent many neighbourhoods in many Arab countries. Through textual analysis, the appraisal of characters and the interpretation of absurd events this 
paper attempts to recognise the political, social and religious foundations on which the stories are based. The essay highlights the ideas behind Tamer's depiction of bizarre events and peculiar characters and clarifies how he portrays the deep crisis in the Arab social fabric, hindering the people's ability to bring about real change. From the very beginning, readers, familiar with Aleppo, expect a grim atmosphere; Tamer's choice of the name Queiq, for his fictitious neighbourhood, foretells what is to unfold; River Queiq is well known to be a dry malodorous and filthy river in Aleppo ${ }^{3}$, therefore the very choice of this name is purposeful. Interestingly, the river becomes, in later years, a symbol of brutality and violence. ${ }^{4}$

\section{Religion, Politics and Culture}

Sour Grapes magnify the various pressures the Arab person has to put up with in life. Many of these difficulties, according to some Western Political scientists and theorists, are generated by Islam, which they argue is incompatible with democracy. Although the current state of affairs sanctions their argument, the social and political defects, which gave birth to an anomalous setup, must be taken into consideration. In The Clash of Civilizations, Samuel Huntington, for example, repeatedly affirms that Muslim countries are unproductive ground for democratic progress. (Huntington, 1996, p217) Mark Tessler also notes Islam's role in shaping political culture and quotes a study, presented at the annual meeting of the American Political Science Association, which says no Middle Eastern Muslim country is "able to escape completely from [religion's] overarching reach" (Tessler, 2002, 217) Although this is true, Islam cannot and must not be held responsible for the tyrannous roles exercised by the patriarchal figures who misuse authority granted to them by Islam.

As a collection of short stories, the work strongly highlights the points of weakness in society; however, the nature of the work does not permit the provision of background explanation of the social maladies and religious misconceptions, generally accepted as common truth, nor their effective role in shaping the status quo. Therefore' I have felt it essential to explain the background, against which Tamer moulds and constructs his characters, to his readers in English to facilitate the full appreciation, of the writer's message, by the non-Arabic speaking world.

Before holding Islam responsible for cultivating dictatorships, it is worth noting that certain practices in some Muslim societies are not part of the teachings of Islam but have simply evolved in the course of time as a result of local cultural and ethnic factors or as the result of interaction with foreign cultures whether colonising or being colonised. Misinterpretations and even intentional negligence, on many occasions, play part in delivering what serves the aims of the few at the expense of the majority. Obedience to the ruler is the Muslim's duty, however and contrary to the dominant discourse, the ruler, in the traditional hierarchical system of Islamic government, must be appointed by the consensus of the nation. He must be capable of carrying out the responsibilities of the role before he can be regarded as God's means for realising His divine will. However, the consensus part of the teaching is often ignored and the misconception is passed from one generation to the other. This hierarchal set up extends to other aspects of life where men, based on the responsibilities attached to their roles, are granted a higher position than women. ${ }^{2}$ 
Although the writer does not explain gender roles and responsibilities, he raises the reader's awareness that inadequate performances necessitate change. Every story points to one or more of the problems that impact Arab life. He also highlights the socio-political fabric and the complicated concepts imbedded in the Arab social and religious structures. The Sour Grapes collection satirically exposes the widely held views, customs, religious and social pressures controlling the Arab person. It raises the reader's awareness of the subjugated and hypocritical existence of both sexes. Through mastery of style and narrative rhythm, Tamer dissects the dehumanising pressures on the people and exposes not only the plight of the Arab woman but the effeminate existence of the Arab man who fails to achieve self-determination.

\section{Subaltern Existence and the inevitable Uprising}

The Arab man occupies the highest rank in the household hierarchy, economy, and in society, therefore, weak indecisive men fail to gain the admiration and respect of not just society but within their households. They are usually dismissed as effeminate and unworthy of being men and are thus comparable to women and seen as physically and mentally weak (Attir, 1985, p. 121). Tamer builds on this concept by depicting male characters as hopelessly subaltern to nondemocratic authority or even a bully thus comparable in their position to the subaltern position of women in society and the colonised existence under foreign rule. Tamer himself describes the relation between the ruler and the people as that of "a tyrant owner and the owned,"5 emphasising the subjugated position of the Arab man.

In Sour Grapes, Tamer highlights the effect of authority on the people; in 'The First Downsize', 'The Black Wings' and 'The Branches' the reader is compelled to question the validity of the concept of obedience and whether this concept is behind the democratic deficit and the authoritarian set up so prevalent in Arab and Muslim countries. Obedience to superiors leaves Abdul-Nabi Al-Sabban in 'The First Downsize' with a very small lung. In full obedience to authority he agrees to undergo an operation to downsize his lungs. The man, arrested for breathing more than his share of oxygen, acknowledges that the size of his lungs is behind this unintended violation. He is referred to hospital only to leave, few weeks later, a completely different man with a narrow chest that consumes less oxygen than is originally allocated.

In this story Tamer not only refers to blind obedience to authority: "O you, who have believed, obey Allah and obey the Messenger and those in authority among you," but to dictatorships that exploit this concept to the extent of rationing people's oxygen consumption. The regime turns life into misery for Umar Yasser in 'The Black wings' where Yasser only smiles when he is dead. In reference to the dreadful existence suffered by adults, the writer explains that Yasser had been a happy child who laughed all the time but had completely stopped on reaching adulthood. Lying in bed, Yasser realises that he has become an old man. The realisation triggers rebellion against the routine he has followed all his life. He refuses to get up despite his wife's numerous warnings lest he is late for work. At that point a burly policeman with two black wings comes out of the closet and orders him to get up or he will be late for work. The black winged policeman in this story refers to the government as the administrator of death ${ }^{6}$. Yasser's reply that he had gained nothing from work over the past fifty years points a finger of accusation at the failure of Arab governments, which, contrary to the religious teachings, require the individual to fulfil the role set for him without expecting anything in return. 
The authority, manifested in the black-winged policeman, carries out the punishment. Whether out of fear or faith, Yasser does not rebel. From the authority's perspective Yasser's rebellion threatens the unity of society and encourages others to follow suit. The policeman's warning that Yasser must get up for work to maintain production or he shall starve (p.175), reminds the reader of Lenin's slogan modified later by Saddam Hussein into: "He who does not produce shall not eat"' . When Yasser insists that he would rather eat wood and soil or even his elderly wife, than go to work, things begin to take a more serious turn. At this point the policeman threatens him with death; 'If you do not work there will be no reason for you to stay alive'. Common good is the pretext authorities utilise to keep people under control. Faith on the other hand requires Yasser and others like him to obey those in charge, even if they disagree (Obedience to the Ruler, Prophet's Mosque Literary Forum) "And if you disagree over anything, refer it to Allah and the Messenger, if you should believe in Allah and the Last Day" (Surat alNissa' 59). ${ }^{8}$ Yasser's reply shows that he has reached a final decision: 'only a crazy fool would hold on to this disgusting life'. This answer is typical of many Arab individuals who feel that the poor quality of life makes it unworthy of living. ${ }^{9}$ Yasser is one of the odd people because he strays away from the flock thus deserves punishment. His death would serve as a deterrent to any other person contemplating rebellion or seeking to challenge tyranny cemented by the silent majority, therefore death is welcomed with a smile.

Tamer foresees that a popular uprising is inevitable; in several stories. In 'The Branches' the students rebel against the oppressive teacher and kill him. In 'Men,' Haleem, the husband, rebels against his wife and divorces her. In 'The Branches' a teacher insults students and forces them to sing the national anthem. The pressure exerted, by the teacher, refers to the pressure imposed on people to sing or cite slogans to demonstrate their patriotism, in other words; it measures their loyalty to the ruler. In defiance the children sing the words of passionate love song to the tune. The situation deteriorates and the students beat the teacher to death. Tamer here is clearly professing that an uprising will take place and the death of dictator is inevitable. The elimination of the teacher restores harmony and the students sing together the national anthem correctly. The solution Tamer provides in 'Men' is yet another prediction of what was to take place ten years later. In the collection, written in 2000, Tamer foresees that continued abuse and exploitation of the simple and good natured individual will lead to revolution. Haleem's tolerance only comes to an end after a series of violations and abuse. In 'The Branches' the reason for the uprising is pressure made clear by the teachers persistence while in 'Men' the case passes through several stages. Nabeela's misconduct is gradual. Haleem's uprising is triggered by a seemingly trivial reason. Nabeela is not divorced for her adultery but for forgetting to add salt to the food. This makes Haleem's decision largely similar to the 'slap', dealt by the Tunisian female municipal official and her aides to Mr Bouazizi. ${ }^{10}$ In both incidents the trivial action signifies the 'straw that broke the camel's back'.

Similarly, in his criticism of regimes, Tamer highlights the futility of expecting governments to take steps towards improving the people's living conditions. In 'Her Fourth Promise', Rima makes a number of promises to Hamdan. She vows to return his love when man first lands on the moon and assures him she would marry him when the Soviet Union becomes a capitalist country and to bear him a son when the Berlin Wall is taken down. All these events do take place, enabling Rima to keep her word. However Rima's assurances that Hamdan's financial position will improve remains unfulfilled even when the impossible condition for its 
fulfilment does takes place; Tamer satirically shows the chronic problem of unemployment ${ }^{11}$ through Rima's unattainable promise. She assures Hamdan that the problem of his unemployment will be solved when the United States becomes a communist country. Tamer allows the incredible to take place to reflect that it is easier for the bizarre to become a reality than for an Arab government to solve the problem of unemployment. ${ }^{12}$. The reader is thus informed that, as Rima had promised; red flags are raised above all the buildings in America, but Hamdan's position remains unchanged.

\section{Social Hierarchy and the Distribution of Roles:}

The distribution of responsibilities in the Arab world is clearly defined through the presentation of the hierarchical setup. Apart from highlighting the poverty in 'Harat Queiq' and its miserable conditions, Tamer draws attention to its impact on the people by illuminating the hierarchy of interdependence. Arab societies are male-dominant where the eldest male figure is the head of the family. Age, wealth, and heritage also play a significant role in determining the status and the extent of dominance enjoyed by the male figure. The patriarchal structure extends throughout all levels of society, making obedience to the head, be it of a household, a clan or the state obligatory. These leaders, each in their own crowd, represent the group to the outside world. He guides their actions and is responsible for their welfare (Al-Krenawi and Graham, 2000). In 'alMuharasha' (The Dog fight) Tamer describes Queiq's men as vicious, who would 'kill their own mothers for money' and their women as famously insolent and Queiq's youth and children as shisha-smoking and drug addicts.

Although this hierarchy does not rise above the ordinary man, knowledge of the Arab social hierarchy, suggests the indirect reference to the role of the government and its responsibility for the miserable conditions in Queiq. The government's neglect left men prone to crime and unable to perform their duties towards their families. This hierarchal concept is consolidated by the authentic and agreed upon Hadith (religious teachings) that every human has a responsibility to fulfil; "The leader of people is a shepherd (guardian) and is responsible for his subjects" (Daily Hadith). Likewise every man "is a shepherd and responsible for his flock" (Ibid). The hierarchy then includes women as shepherdesses in their husband's property and responsible and lastly the servant who is responsible for the masters' property. Had the men in Queiq been in a better position, their women would not have become famous for their rudeness and the children would have been in school. Although Tamer does not point a finger of accusation at a certain figure or government the hierarchal arrangement he describes clearly refers to the social structure.

\section{Women, Teachings and Social Customs}

The fact that the conduct of women appears frequently reflects not only the prioritisation of shame and honour but the importance of women's conduct in society. However Tamer sometimes blends several problems in the representation of one woman; in 'Men', the 'Fez Wearer, 'The Black Wings' and others, Tamer, permits two or more different levels of interpretation. By highlighting the wife's misconduct, in 'Men', for example, Tamer draws attention to a number of problems, predicting that a revolution will eventually break out against tyranny. Through the behaviour of Nabeela, Tamer presents, along with the political connotation of the story, the reality of men's misappropriation of their right to divorce. 
The name of Haleem, the Arabic equivalent of tolerance, is given to emphasise the political element in the unrealistic tolerance over his wife's misconduct; like a dictator, Nabeela, whose name is the Arabic equivalent of noble, takes advantage of her husband's tolerant nature; apart from her simple violations of social conduct such as throwing away the Milaya ${ }^{13}$ and speaking to strangers, she goes as far as committing adultery and gives birth to her lover's child. This unlikely tolerance of an Arab husband and his attempts to gently warn his wife against a bigger mistake and her intentional disregard of his wishes consolidates the notion that Tamer intends a political interpretation of the story in which Nabeela becomes more of a tyrannical figure than an Arab wife. When her husband finally decides to exercise his right he does so in reaction to a trivial matter.

Taken at face value, the story highlights man's misappropriation of his right to divorce; the ease in which Haleem pronounces the divorce words is repeated in the 'Fez-Wearer' where Al-Haf, who brags about his love for his wife to his friends, divorces her for nagging him to stop wearing the fez. Regardless of the deeper interpretation of the stories, the ease and the convenience permits the whimsical exercise of the right granted to men over women. In a real life situation Nabeela's punishment for her misconduct would be very harsh ${ }^{14}$. Although Tamer has no sympathy for women who defy conventions, his satirical comments compel his readers to challenge the whole set of conventions imposed on both men and women, while the political interpretation of 'Men' reflects the rise of the tolerant human being against the abusive power. The presentation of characters and events incriminate the patriarchal setting and the 'shepherds' who abuse their rights over their charges.

In 'al-Muharasha' Um Ali, a notorious widow with no authoritative male figure in her life is aggressive and sharp tongued. This behaviour is her strategy of self-defence and to protect her daughter from young men seeking her acquaintance. When Abu Saleem, the barber, stops her to deliver a message she shows no interest and mockingly assures him that she will ask for his services 'when her beard grows' (Al-Maharsha, p. 14). However her tone becomes more lenient when she learns the message is from Naguib al-Baqqar, the richest man in Queiq. In his description of Umm Ali, Tamer draws attention to gender differences even among criminals; he writes that Umm Ali would have been 'a permanent jailbird had she been a man'. However this does not rule out that she may have been imprisoned at some point in her life. This description allows comparing Umm Ali with thugs, usually former criminals or unemployed individuals with a criminal tendency or record, renting their skills, to make money. Umm Ali rented her sharp tongue to a representative of power who used her to settle his account only to side-line her when she was no longer needed.

Umm Ali is thus exploited by the powerful to fight by proxy in a power-struggle between two men in return for money. Representing power and wealth, Al-Baqqar seeks to humiliate Khudir Alwan who, the reader learns, is so vicious he had cut and eaten his ear in court to the horror of the judges. The choice of Umm Ali for the task highlights two objectives: firstly; it secures the total humiliation of Alwan without him being able to retaliate. Secondly hiring Umm Ali to do the dirty work protects Al-Baqqar from direct confrontation with a man of Alwan's character. Alwan's male pride will prevent him from taking revenge on a woman and so he stands: 'helpless and blue-faced' listening to the insults pouring out of Umm Ali's mouth. 
The lower position of women in society prevents Alwan from striking back at an unequal therefore he breaks Umm Ali down by killing her nephew, whom she loves more than a son. Tamer comments that the lower working classes are cunning in their ways; if Alwan had arranged to take his revenge by raping the daughter; Umm Ali's voice would have been louder than ever before ${ }^{15}$. The choice to murder Suleiman has a permanent destructive impact on Umm Ali and leaves her incapable of resuming her old self. What seems to consolidate Tamer's reference to a power struggle is the celebration held by Al-Baqqar on Alwan's release and his acquittal from what Al-Baqqar describes an 'unreasonable' charge.

Although Umm Ali saw the murderer and heard her nephew beg the assailant to stop, Alwan manages to evade prosecution. Tamer explains that Alwan got twenty men to witness he was with them at the time of the crime. Apart from the criminal aspect of the crime, Suleiman's death emphasises the price males pay for their social superiority. Umm Ali's devastation, on the other hand, shows, apart from her love for him as an aunt, women's exaltation of men relatives as a source of strength; this exaggerated superiority does not just affect women but can be very disadvantageous to the men themselves who, at times, are held responsible for the conduct of their women. This is more apparent in day-to-day relations where women have to obtain men's consent over most of their out-of-doors activities.

The protection of women often creates a parasitical relationship; in return for the restriction of freedom, women are fully kept even if they had their own means. This stems from women's importance in preserving the family honour. The concept goes back to the days of pagan Arabia when female infants were buried immediately after birth. The reasons for eliminating female babies were poverty and the fear of shame women may bring upon their tribes if they were to be taken among the spoils in an enemy raid (Al-Samman, 2010). Thus it can be inferred that this fear created an exaggerated form of protection that led, with the religious taboos on premarital sex and the superiority of men, to the subjugation of women and the suppression of their sexuality ${ }^{16}$ as is demonstrated in Umm Ali's fear over her daughter and the lowering of Layla's dowry, for losing her virginity, in the 'Old Dress' ${ }^{17}$.

The people's anticipation that Umm Ali's daughter will be kidnapped and raped as part of Alwan's revenge is another reference to the violation of women as a means for punishing male members of the family or the tribe ${ }^{18}$. The raped girl becomes a source of shame and the family tries to give all sorts of concession to mend what cannot be mended. In the 'Old Dress' Layla is kidnaped by her own fiancé, however this does not change the fact that she is no longer regarded as innocent and lowers her value in the marriage market. She is described as a second-hand dress, which entitles the groom to negotiate lowering the dowry (149).

The need for Arab women to adjust, in the absence of a man, can be seen in the characters of the defeminised Umm Ali in 'Al-Maharasha' and the over-feminised Na'ila in 'Rain'. Umm Ali is mannish with a bad temper, warding men off, and Na'ila's vulnerability deprives men the bliss of sleep, worrying about her. Umm Ali's behaviour repels men interested in her daughter while Na'ila attracts every man, triggering in him the urge to protect her. Umm Ali and Na'ila and other female characters reflect the position of the unprotected female and the need to survive in a male-dominated society; by acting hostile, Umm Ali transcends gender barriers whereas Na'ila exaggerates her vulnerability to receive protection. When pain reduces 
Umm Ali to an imbecile, walking in a trance with her 'head lolling left and right', she becomes feminised and no longer capable of protecting her daughter, which revives men's hopes in courting the daughter. Na'ila's defiance of conventions differs from that of Nabeela in 'Men'. In Nabeela's case her defiance of social customs and religious teaching is committed with a man in her life and deserves punishment. Na'ila's defiance of conventions reflects the dated misogynist customs imposed on women, sexual frustration and social hypocrisy. By presenting the character of Na'ila, Tamer shows a different survival tactic than the one adopted by Umm Ali

To avoid the position of the unprotected female, Na'ila invites every man to protect her by becoming more feminine. Much younger than Umm Ali, she has the advantage of surrounding herself by a number of male protectors eager to offer their services. However, Tamer satirically refers to the problem of loveless marriages by describing Na'ila's transformation; shocked by the news of her husband's death, Na'ila transforms completely. Firstly she is engulfed in profound reverence; she bends to kiss the floor and screams: "God! You are great". Initially it is unclear whether she praises God in surrender to the Almighty's will or in disbelief at the opportunity granted to her. What unfolds seems to support the second point of view because Na'ila breaks both the Islamic rules and the social conventions of mourning ${ }^{19}$. By not acting the conventional way, the writer introduces the reader to the conventional etiquette of mourning. Na'ila, we learn, does not cry, scream or slap her face as is expected of an Arab wife but throws away all that reminds her of her husband. In a satirical tone Tamer clarifies that in her distress she forgot to wear the traditional long black dress and head cover to the funeral. Instead she wore a short tight red dress, far 'above her ivory knees'.

Tamer does not openly criticize Na'ila, yet his description of her conduct raises awareness among readers, familiar with Arab customs, that she has flagrantly breached the code of conduct Arab widows are required to follow. By not doing the 'done thing', Tamer magnifies that loveless marriages do exist whether widowed women observed the customs or not. Tamer's depiction of Na'ila does not highlight her ill conduct as much as it proves a major point; Na'ila's improved health. The transformation clearly demonstrates that she may have been under mental or physical stress. By destroying all that reminds her of her husband, her hopes in a better life are revived. This is well captured by Tamer when he assures the reader that her grief "transformed her from a woman in her thirties, into a rosy-cheeked girl of twenty". Tamer's sarcasm is further directed at society and men's hypocritical attitude towards vulnerable women. This reaches its peak in the concluding sentence: 'since then, all men, married and single, visited her in an effort to console the woman who refuses to forget her husband'.

Magnifying the unusual highlights the problematic position of women in society whereas the need to adjust reflects the fear experienced by single women who have to survive on their own in a male-dominated society. The need to adjust becomes essential otherwise she is prone to fall victim to the sweet talk of insincere men. Na'ila's for example, sells the house to get rid of all that reminds her of her husband, but continues to hide behind the claim that she cannot forget her him. Women, in 'A Man for One Woman', and 'The Divorced' fall victims to immoral men. In the first story Tareq, a young unemployed man from Queiq, takes advantage of Samia, a rich lonely woman yearning for marriage and children. Tareq, whom she meets on the bus, succeeds in taking her to bed almost immediately. Lying next to him, she dreams of married life and a house full of children while he, believing her to be disreputable, contemplates sharing her with 
his friends in return for a modest sum. In the second story a widow enjoys being raped on visiting her husband's grave. What seems to be lack of sympathy for women on Tamer's part highlights the fragile position of a man-less woman; when the rapist learns that her husband has been dead for a year he assumes she would accept him. He murmurs to her: "a whole year without a man is unbearably painful" (p.51). Despite the fact that rape cannot be justified, Tamer here resorts to the uncommon or even the grotesque to highlight two things firstly; how man-less women are taken advantage of in society and secondly; how sexual deprivation can trigger the instinctual trait inside men and women. This biological desire blinds the widow to the point of accepting a 'stern-faced, fat and short' male next to her husband's grave.

Although Tamer appears to show no compassion for his female characters, it is highly unlikely that this cynicism is directed at women. As in all the collection Tamer magnifies ugliness to highlights the quality of life, the impact of dictatorship, the colonised human being and the suppressed human desires. In both stories the male characters are perverts and the females are vulnerable, thus he warns that suppressed passions will undoubtedly lead to dire consequences. Tamer pronounces the end of the widow's commitment to the memory of her spouse when the husband turns in his grave and pronounces the divorce phrase.

Gender inequality reappears differently in 'Death of a Dagger' along with the abuse of authority. Through Alwan's imaginary friend Antar, a famous Arab knight of ancient pagan Arabia, Tamer reminds the reader that the prevalent concepts are no longer suitable. He refers to the modern world through the advice given to Alwan by his mother. As a traditional Arab woman, with a grownup son, her main desire in life is to see him married with children. However the ear he ate in court made him repulsive to women so she advises him to resort to plastic surgery. Alwan dismisses the idea, muttering to himself that he will take no advice from women because they are half-witted. This saying, reiterated by many Arab and Muslim men, is in fact based on a saying attributed to Prophet Mohammad emphasising women's deficiency of mind and religion" (Rafiqul-Haqq, M. and Newton, P. 1996). Although Muslim scholars went to great lengths to explain the wisdom behind the saying, the deficient mind of women became a generally accepted truth.

Women's vulnerability in the Arab mind makes her inferior. This is clearly detected in Antar's advice to Alwan about his dagger. The confiscation of the dagger by a policeman is humiliating because it unmans Alwan; Antar confirms that the dagger and the sword are a man's honour and are more important than the beloved. He stresses if he had to choose between the two he would certainly choose the sword because a man with no weapon, is like "a woman, vulnerable to rape" at any time. This also highlights the effeminate existence of man without a weapon to secure his manhood. Antar, whose sword won him his beloved despite class differences, also says man without physical prowess will be targeted by the birds of prey. Alwan, lost and humiliated without his dagger, asks Al-Baqqar to exercise his influence on the police to recover it and is devastated to learn that the policeman has not handed it in but has sold it to a Western female tourist who was flying home on the same day. Although it is common to carry daggers and knives in most Arab countries, the policeman, given that Alwan is an outlaw, can confiscate it if he feels like it. However selling the dagger, man's source of pride according to Antar, to a tourist exposes not only corruption and abuse of authority, but raises the question of whether Tamer is hinting at the authority's allegiances with the West, selling them treasures be it 
AWEJ for translation \& Literary Studies Volume, 1 Number 2, May 2017

Bans and Boundaries: The Arab Layman in ZakariaTamer's Sour Grapes Witwit

natural resources, antiquities or any traditional symbol of Arab dignity. This is further clarified in 'The Fez wearer' where the man refuses to take his Fez off.

Through highlighting Alwan's friendship with Antar, Tamer points that the concept of physical strength, inherited from Bedouin customs of ancient Arabia, remains valid to this day. Many Arab societies continue to insist that man's life is outdoors with other men and any man, preferring the company of women is weak and feminine and is looked at with disrespect. By killing Alwan in a car accident, Tamer highlights that only death can solve the problem of lost masculinity.

\section{National Identity and the struggle to preserve it}

In 'The Fez-wearer' man's right to divorce is present but secondary to the concept of national identity vs colonisation. Tamer highlights the French colonisation of Syria from a postcolonial position and presents the colonised person's side of the argument through the struggle of Mansur Al-Haf to keep his national identity represented by the Fez. Although Al-Haf is tough, he is by Arab standard a fair man because he only uses his dagger in self-defence. The theme of dissatisfaction with life reappears when Al-Haf says: 'only a fool would prefer the bigger prison [of life] to the small one'. Although he is too shy to confess his love to his wife, Naziha, he openly admits to his friends that 'her wish is his command' and he would not hesitate to shave off his moustache if she wanted him to ${ }^{20}$. However he strongly turns against her when she advises him to stop wearing the $\mathrm{Fez}^{21}$. Al-Haf scornfully tells his wife that the Fez ornaments men like the traditional Milaya ornaments women and the leaves and branches decorate trees.

Tamer uses the Fez to highlight the coloniser's threat to national identity and the various means employed to obliterate it. The story, set during the French mandate in Syria and Lebanon in the early twentieth century, presents the coloniser's attempt to impose his own culture by wiping out that of the colonised. The French General Henri Gouraud ${ }^{22}$ offers Al-Haf money and privileges in return for his fez, but Al-Haf refuses. This refusal explains Al-Haf's antagonism and reaction towards his wife when she demands that he should choose between her and the fez. The fez in this story symbolises patriotism and national identity which Al-Haf cannot compromise and holds on to the very end. At face value his action, like that of Haleem, highlights the misappropriation of man's right to divorce. At a deeper level Al-Haf, who would willingly shave the symbol of his masculinity for Naziha, refuses to compromise his national identity despite his deep love for her.

When Al-Haf utters the divorce phrase three times ${ }^{23}$, Naziha becomes a total stranger and must leave the house. Finding herself alone and 'shepherd-less' she cries "wa Gawrah"in reference to General Gouraud. Tamer in this story satirically blends past and present, telling his readers that the French general, like the Arab Caliph heard Naziha's call and marched to Syria ${ }^{24}$. Tamer also emphasizes the West's historical animosity to the East when he informs his reader on Gouraud's visit to Saladin's grave. The French general 'tainted with the blood of Syrian men' addresses the grave, by saying: 'we are back again'. Saladin's reply, from inside the grave, highlights the transitory nature of any foreign occupation, confirming that the French's unjust presence will be met with resistance and will have to end one day: 'in the voice of a land, washed by sudden rain that wiped away its tears and revived its power of speech', Saladin replies: "you will return home one day in black coffins" (p.162). Gouraud, surrounded by his guards and 
equipped with all types of modern weapons, acts as if intending to stay permanently in Damascus, orders all Syrian men to stop wearing the Fez. Tamer stresses that although many people collaborated or simply obeyed, there are ones, like Al-Haf, who adhere to their principles and beliefs. Al-Haf meets his death for refusing to take off or sell his Fez, insisting that man's death in defence of his Fez is the greatest honour anyone could ask for. Tamer shows how impossible it is to strip one's identity, stressing that despite all attempts identity will remain as long as people like Al-Haf existed.

Tamer uses the Fez as a symbol of both cultural identity and dignity and the struggle to hold on to them despite the coloniser's efforts to eliminate them, stressing that all the French soldiers' attempts failed to take the Fez off Al-Haf's head after his execution in order to send for analysis in France. This reflects the West's inability to comprehend the values of the East and the Fez escapes from the French, moving from one Syrian to the other; from the patriotic to the opportunist, finally falling in the hands of the new generation; 'it was seen for the third and last time as 'a jolly red ball' in the hands of laughing children' (p.166). Tamer's message maintains hope that all forms of dictatorship whether foreign occupation or autocratic rule cannot eliminate one's national identity and belief as long as the people continue to live.

In 'The Silent' Tamer highlights false praise, lies and cajolery as a wide-spread social disease. This disease, if tied up with obedience and fear, a tyrant is created. The story translated into English as 'Slap' heightens dishonesty as a culturally imbedded disease. The slaps resemble the pangs of conscience, irritating hypocrites; Zhuhair Sabri receives his first slap when he tells a woman, offering him sincere love that he cannot think of anything other than his future. However the second and third slaps best clarify the theme; Sabri is slapped again when he told a rich man that he is the greatest man ever born to the country and a third time on kissing the hand of a cleric with a long ragged beard and asking him to pray for him. On all occasions, Sabri does not see his slapper but continues to be slapped on daily bases. Although he does not tell anyone in case they doubt his sanity, he was certain that everyone was being slapped like he was and all remain silent.

\section{Conclusion}

Apart from predicting the Arab Spring, Tamer intelligently names the collection Sour Grapes in reference to the biblical saying; 'The parents have eaten sour grapes, and the children's teeth are set on edge' or 'pucker at the taste' (Jeremiah, 31:29). ${ }^{25}$ This widely used saying, regardless of religious affiliations, hints that the difficulties facing the Arab person are not the making of today but of past generations. The accumulation and the various interweaving cultures, races and religions that entered the Arab homeland over centuries, turned various beliefs, even alien and pagan customs into rules which the majority blindly follow. Although the collection paints a grim picture of Arab life, Tamer does not eliminate hope but highlights the inevitability of change. However, what stands out in the collection is the desolate and dissatisfied existence of the Arab person; men welcome death with a smile and women camouflage their nature to survive. The collection also reveals a similarity between the colonised existence of the individual under foreign occupation and those living under autocratic regimes that ration his intake of oxygen and force the Arab individual to work against his will. Although Tamer does not explicitly refer to the causes, he skilfully highlights the effect, pressing heavily on the sore spots 
of Arab life, forcing the reader to stop and think about the aspects of Arab life that require change.

The collection is an eye opener for the Arab reader. It compels him/her to stop and think whether to continue living this anomalous existence or seek change. It triggers the urge to pursue the genuine religious teachings and discard all that is pagan and alien. These short stories deliver disturbing message on the state of affairs and the need to re-examine Arab priorities in order to provide a better life for future generations. The writer's prediction on the re-colonisation of the region was his way of warning people that unless the oppression of unnamed regimes, hypocrisy, and lack of self-expression are eliminated, there will not be an honourable existence. Tamer demonstrates how the one-sided interpretation of the Islamic command, to obey the leaders, has confiscated the people's right to challenge them. Through presenting the physical and mental anguish in the form of hyperbole or as a nonsensical event Tamer seeks to magnify the deep crisis governing Arab existence. The fact that it was written before the occupation of any Arab country or the break-out of any Arab uprising, justifies Tamer's message, urging Arabs to reassess the quality of their life think of their destiny.

Tamer's creativity grants his readers the joy of interpreting and evaluating the significance of every strange metaphor and ridiculous event, forcing them to question the credibility of the bases on which customs stand. Tamer masterfully shows the effeminizing impact of the state on men and that men, in the larger hierarchy, suffer a "powerless, subservient, and submissive" existence like women in society (Al-Haj, 1987, p. 103). This interdependent submission leaves both men and women incapable of making important decisions without gaining consent, thus any independent-thinking individual, appears defiant and deserving punishment.

\section{Notes}

1. Zakaria Tamer, interview with author. (12 February 2016).Tamer comments that the Iranian ambassador demanded that he be executed for disrespect. He was summoned by the Intelligence but managed to convince them that he had not intended any criticism for the Shah and the article was purely imaginative.

2. Surat al-Baqara': 228 makes clear that men are superior to women by one degree .Women as witnesses are counted as half a person. Surat 'Al-Nisa':34 explain that men are the guardians of women because God has made them more superior, and because of the money they spend on keeping the women. Therefore virtuous women are obedient, and guard their chastity and the husband's interests, (such as his property) in his absence. As for those who show a tendency for disobedience, men should at first caution them then desert their beds and finally beat them. If they obey, then men should not seek a way against them. Part of Surat un-Noor, however, holds males and females equally accountable before the Law.

3. Queiq River dried up completely in the late 1960s, due to irrigation projects on the Turkish side of the border.

4. Tamer's choice appears as an accidental prophecy; since January 2013 Queiq River has become associated with a massacre claiming the lives of approximately 110 men and boys. They were found shot with hands tied behind their backs and mouths sealed with tape on the edges of Queiq River in a part of Aleppo controlled by opposition forces.

5. Interview with the writer on the 12/02/2016 
AWEJ for translation \& Literary Studies Volume, 1 Number 2, May 2017

Bans and Boundaries: The Arab Layman in ZakariaTamer's Sour Grapes Witwit

6. Tamer clarified that the black wings refer to the angel of death. 12/02/2016

7. Lenin's basic and root principle of socialism: "He who does not work, neither shall he eat," was modified by Saddam Hussein to become one of the Arab Ba'th Socialist Party slogans.

8. There are also over eighty hadiths (sayings) attributed to Prophet Mohammed, urging people to obey their leaders.

9. Welcoming death is a familiar expression; the word is used for describing various situations; it is used to exaggerate various feelings. A person could describe himself as dying from hunger, dead tired and craving death due to unrequited love and even tell the beloved that he/she would die for and in their love.

10. Mohamed Bouazizi is a Tunisian street vendor whose self-immolation catalysed the revolution in Tunisia and helped spark wider pro-democracy protests in the Middle East and North Africa. Allegedly he was publicly humiliated by a female police officer who slapped him. When Bouazizi was denied a hearing with the governor to complain, he, later that day, set fire to himself outside the governor's office, sustaining severe injuries.

11. According to Don Tapscott "twenty-four per cent of young people in the region cannot find jobs" (Guardian: 2011).

12. The problem of unemployment in Syria, and the Arab region in general continues to create economic insecurity among the people.

13. Black cotton fabric sewn along the long edge then wrapped about the body over normal clothing. It is worn by urban women in Egypt and other Arab countries. It is held under the armpits at one end with the other end draped over the arm. This exposed end was sometimes a special piece with additional shaping and texture. The Malaya could also go over the head forming a veil.

14. Arab penal codes for adultery differentiate between men and women. Apart from the customary action of honour killing, the law is more lenient with men. A man is only sentenced if the act takes place in the marital home and the sentence varies between three months and one year. Women receive a two-year imprisonment regardless of the location in which the act takes place.

15. Interview with author 12/02/16. Mr Tamer says Umm Ali is a real person from a nearby neighbourhood and the events he describes are real.

16. The majority of Arab women work out of financial need. Even today many women still expect to leave work on marriage unless they gains the husband's consents. However most married working women still expect to be fully kept by their husbands even if they have a salary. 17. In Arab and Muslim countries, the family honour is still measured against the virginity of their daughters. In rural and some urban regions, a proof of virginity is required on the wedding night. For further information please consult Reading Arab Women's Autobiographies by Nawar Al-Hassan Golley, Austin: University of Texas Press, 2003

18. Rapists tend to avoid punishment by marrying their victims. However if this does not take place the woman is further punished by her family or tribe. Many either kill themselves or are killed by their families to wash off their shame with blood. This is still practiced in Arab countries where tribal laws are more influential than civil laws.

http://english.alarabiya.net/en/views/news/middle-east/2014/05/17/Will-Jordan-ever-abolish-itsdraconian-rape-law-.html accessed 21/02/2016

19. Although Islam does not encourage mourning for more than three days, the situation differs in the case of women mourning their spouses; they are required to remain in mourning for a longer period of time. Religious legislations stipulate widows mourn for four months and ten 
days. The idea behind it is to make sure that the woman is not pregnant. On a social level, class and education play part in determining the time and etiquettes of mourning. Women with children are expected to mourn longer than childless women. In general, most women are required to mourn at least a year after the husband's death.

20. Thick, moustaches have long been prized by men throughout the Middle East as symbols of masculine virility, wisdom and maturity. For a man to shave his is to relinquish all these traits. 21. Initially the fez was a symbol of Ottoman modernity. Over time, the fez came to be seen as part of an "Oriental" cultural identity. For Middle Eastern Arabs it also symbolizes literacy and distinction.

22. Gouraud served from 1919 to 1923 as representative of the French Government in the Middle East. During the Franco-Turkish war, he presided over the creation of the French Mandates in Syria and Lebanon.

23. Divorce (Talaq) In Islam requires the husband to pronounce the phrase "You are Taliq" (I divorce you) to his wife. A man may divorce his wife three times, taking her back after the first two (reconciling). After the third Talaq they cannot get back together until she marries someone else.

24. Tamer refers to the story of a Muslim woman, held captive and humiliated by the Romans. The woman cried out in distress the name of the Abbasid Caliph Al-Mu'tașimbi'llāh (796-842) son of Hārūn Ar-Rašīd; (763 or 766-809). The prefix [Wa] and the suffix [mah] "Wa Mu'tasimah!" are used to call someone far in distance whom the caller feels can be his/her saviour. The cry reached the caliph, thousands of miles away, and he set to save the woman. Arab historians mention this among the reasons that triggered Al-Mu'tașim's attack on Amorium, the birthplace of the reigning Byzantine dynasty in 838AC.

25. This biblical saying is widely used among Arabs in Middle East regardless of religious affiliations. It is used to express that the successors pay for the flaws of their predecessors.

This work is part of the author's Leverhulme post-doctoral fellowship

\section{About the Author:}

Dr. May Witwit is a Hon. Research fellow at the University of Bedfordshire and Associate Member of the Centre for Cultural, Literary and Postcolonial Studies (CCLPS).Her research interests include Victorian anti-suffrage and the policy of British Empire, the position of the Victorian women, Victorians' interest in Arab life in addition to modern Arabic literature. Her current research looks on the representation of Arab women in Englishworks of literature and whether these past representations form the basis of today's Islam-phobia and the stereotyping of Arab women.

References

Al-Haj. (1987). Social Change and Family Processes. London: Westview, 83

Al-Krenawi, A., \& Graham, J. R. (2000). "Culturally Sensitive Social Work Practice with

Arab Clients in Mental Health Settings". Health and Social Work Journal Feb; 25(1):922.

Al-Samman, H. (2010). “Arab Women Writers between Shahrazad's Memory and the 
AWEJ for translation \& Literary Studies Volume, 1 Number 2, May 2017

Bans and Boundaries: The Arab Layman in ZakariaTamer's Sour Grapes Witwit

Nightmare of Infanticide." Alif: Journal of Comparative Poetics (Department of English and Comparative Literature, American University in Cairo and American University in Cairo Press) (30): 73-97.

Attir, M. O. (1985). "Ideology, Value Changes, and Women's Social Position in Libyan

Society." Women and the Family in the Middle East; New voices of change, edited by E. W. Fernea, Austin: University of Texas Press, 121-133.

Huntington, Samuel P. (1996). The Clash of Civilizations and the Remaking of World Order. New York: Simon \& Schuster, 127.

Jeremiah. (n.d.). New King James Version. Blue Letter Bible, 31:29.

Mustafa M. (2012). "Obeying the Guardian is Obligatory According to the Qur'aan, Sunnah and the Consensus of the Ummah". (Retrieved from Al-Maktaba Prophet's Mosque Library Forums: http://www.mktaba.org/vb/showthread.php?p=69306

Rafiqul-Haqq, M, Newton P. (1996). “The Place of Women in Pure Islam”. Retrieved from http://answering-islam.org/Authors/Newton/women.html\#sup.

Tamer, Z. (2000). Sour Grapes. Beirut: Riad El-Rayyes Books S.A.R.L

Tessler, M. (2002). "Islam and Democracy in the Middle East: The Impact of Religious Orientations on Attitudes toward Democracy in Four Arab Countries." Comparative Politics 34, (3), 217. 